【論文】

\title{
振動細線法による気体の粘性係数測定装置の開発 Development of Gas Viscosity Measurement System with Vibrating Wire Method
}

\author{
吉村幸祐 $*$ 上原帝臣* 新里寛英** 久次達也* \\ 迫田直也 $* * * *$ 河野正道 $*, * * * \quad$ 高田保之 $*, * * *$ \\ Kosuke Yoshimura, Temujin Uehara, Kan'ei Shinzato, Tatsuya Hisatsugu,
Naoya Sakoda, Masamichi Kohno, and Yasuyuki Takata
}

高圧・高温の条件下における水素の粘性係数を測定することを目的とし，少量の試料で測定可能な 振動細線法を用いた粘性係数測定装置を $1 \mathrm{MPa}$ 以下の低圧域を対象として新たに開発した. 本研究で 採用した振動細線法では磁場中に設置した半円型ワイヤに交流電流を流し，その振動の減衰と気体の 粘性の関係から粘性係数を算出する方法である。半円型ワイヤにはタングステン, 磁石はサマリウム コバルトを使用した。この装置を用いて, 室温と $50{ }^{\circ} \mathrm{C}$, 圧力 $1 \mathrm{MPa}$ 以下の条件で, 測定の重要なパ ラメータである内部摩擦係数を決定した後, 窒素, ヘリウムおよび水素の粘性係数を測定した.

For the purpose of viscosity measurements of hydrogen at high pressures and high temperatures, a new system with the vibrating wire method that requires only a small amount of sample was developed for the viscosity measurements at low pressures below $1 \mathrm{MPa}$. The vibrating wire method is the way to supply current to a wire set in the magnetic field and determine the viscosity of the sample fluid by the oscillation of the wire. A curved semi-circle wire made of tungsten and samarium cobalt magnets were adopted in this study. The internal friction coefficient, an important apparatus constant, was measured first at room temperature and $50{ }^{\circ} \mathrm{C}$ under $1 \mathrm{MPa}$. Then, the viscosities of nitrogen, helium, and hydrogen were measured under the same conditions.

[Keywords: hydrogen, thermophysical properties, vibrating wire, viscosity]

\section{1.はじめに}

近年，地球温暖化等の環境問題を受け，新たなエネル ギー社会の実現が必要とされており，水素はその優れた 特性からクリーンなエネルギーキャリアとして大きく注 目されている。近い将来の水素利用社会の実現を目指し, 現在，燃料電池自動車や水素ステーション等の開発が活 発に行われているが, 水素は $80 \mathrm{MPa}, 400^{\circ} \mathrm{C}$ 以上の高圧・

* 九州大学 大学院工学研究院 機械工学部門, $\bar{\top} 819-0395$ 福 岡市西区元岡 744

Department of Mechanical Engineering, Kyushu University, 744 Motooka, Nishi-ku, Fukuoka 819-0395.

FAX: 092-802-3128

E-mail: sakoda@mech.kyushu-u.ac.jp

** 九州大学 水素材料先端科学研究センター, $\bar{\top} 819-0395$ 福 岡市西区元岡 744

Research Center for Hydrogen Industrial Use and Storage, Kyushu University, 744 Motooka, Nishi-ku, Fukuoka 819-0395.

*** 九州大学 カーボンニュートラル・エネルギー国際研究所, 厂819-0395 福岡市西区元岡 744

International Institute for Carbon-Neutral Energy Research (WPI-I2CNER), Kyushu University, 744 Motooka, Nishi-ku, Fukuoka 819-0395.
高温状態に至ることもあるため, このような高圧・高温 の水素を取り扱う際には，機器をより安全かつ効率的に 設計，開発することが重要である．そのためには熱物性 值が正確に知られている必要があるが，現状では水素の 高圧・高温域の実測值データは不足しており，低圧・低 温域のデータを外挿することによって推算しているため, その信頼性を確認する必要がある。過去に測定された水 素の粘性係数のうち, $10 \mathrm{MPa}$ 以上の圧力まで測定してい る文献およびその $P-T$ 線図上での分布を表 1 と図 1 に示 す.表 1 では測定された年と測定法，不確かさ，試料純 度，温度と圧力の領域を示しており，OD (Oscillating Disk Method)は振動円盤法，CT (Capillary Tube Method)は細管 法, FCB (Falling Cylindrical Body Method)は落下円柱法, RT (Rankine-type Viscometer)は Rankine 型粘度計を意味し ている. 図 1 に示すように高圧・高温域における水素の 粘性係数の実測値は十分でない，そこで我々は高圧・高 温域における水素の粘性係数を高精度に測定し，信頼性 の高い推算式を構築することを最終的な目的としている. 
Table 1 Previous viscosity measurements of hydrogen at high pressure.

\begin{tabular}{|c|c|c|c|c|c|c|}
\hline Reference & Year & Method & $\begin{array}{c}\text { Uncertainty, } \\
\%\end{array}$ & $\begin{array}{c}\text { Purity, } \\
\%\end{array}$ & $\begin{array}{c}\text { Temperature } \\
\text { range, }{ }^{\circ} \mathrm{C}\end{array}$ & $\begin{array}{c}\text { Pressure } \\
\text { range, } \mathrm{MPa}\end{array}$ \\
\hline $\begin{array}{l}\text { Hongo and } \\
\text { Iwasaki [1] }\end{array}$ & 1978 & OD & 0.3 & 99.99 & $25-100$ & $0.1-12.8$ \\
\hline Gracki et al. [2] & 1969 & CT & $0.1-0.2$ & 99.95 & $-100-25$ & $0.5-17.2$ \\
\hline $\begin{array}{l}\text { Rudenko and } \\
\text { Slyusar [3] }\end{array}$ & 1968 & FCB & $4-6$ & ns & 27 & $0.1-217$ \\
\hline $\begin{array}{l}\text { Tsederberg et } \\
\text { al. [4] }\end{array}$ & 1965 & $\mathrm{CT}$ & 3 & ns & $16-717$ & $4.4-51.2$ \\
\hline Barua et al. [5] & 1964 & CT & 0.2 & 99.96 & $-50-150$ & $1.0-17.8$ \\
\hline $\begin{array}{l}\text { Golubev and } \\
\text { Petrov [6] }\end{array}$ & 1953 & CT & ns & ns & $15-250$ & $0.1-81.1$ \\
\hline $\begin{array}{l}\text { Michels et al. } \\
\text { [7] }\end{array}$ & 1953 & RT & ns & 99.8 & $25-125$ & $2.7-192$ \\
\hline Kuss [8] & 1952 & $\mathrm{CT}$ & 2 & $\mathrm{~ns}$ & $25-75$ & $0.1-50.7$ \\
\hline
\end{tabular}

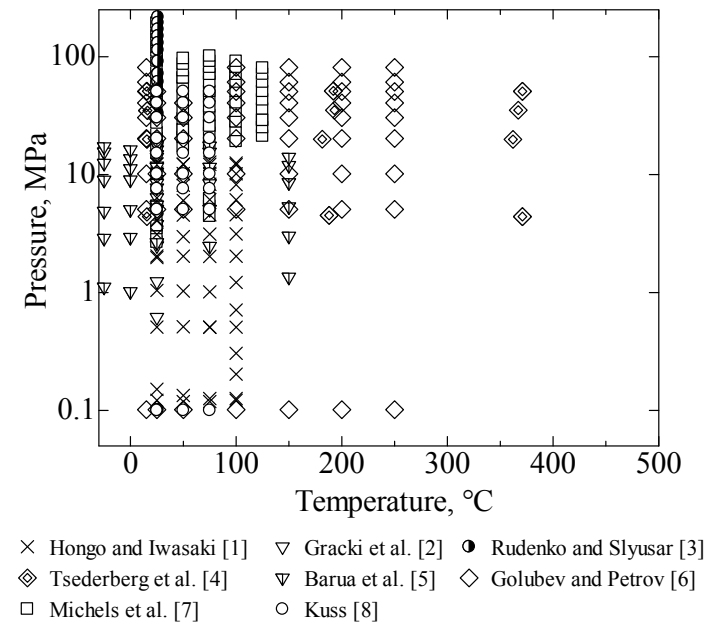

Fig. 1 Distribution of the previous viscosity measurements of hydrogen at high pressure summarized in Table 1.

本研究では, これまでに内径 $0.1 \mathrm{~mm}$, 長さ $400 \mathrm{~mm}$ の石 英ガラス管に試料気体を流し, その際の圧力降下から粘 性係数を算出する細管法を用いて, 室温から $450{ }^{\circ} \mathrm{C}, 5$ $\mathrm{MPa}$ から $99 \mathrm{MPa}$ までの水素の粘性係数を測定した[9]. そ して, さらに低圧域におけるデータの取得と, 細管法で 得られたデータとの相互確認, また細管法のように試料 を多量に必要とせず，少量の試料のみで $100 \mathrm{MPa}, 500{ }^{\circ} \mathrm{C}$ までの高圧・高温域における水素の粘性係数を $2 \%$ 程度の 不確かさで測定できるような計測技術の開発をめざし, 今回新たに, $1 \mathrm{MPa}$ までの低圧域を対象とした半円型振動 細線法を用いた粘性係数測定装置を開発した，振動細線 法は低温流体の測定に用いられた方法であり, 気相域に おける粘性係数も精度よく測定可能である.これまでの 振動細線法はワイヤの形状が直線であるものが多いが, 液体へリウムに対して半円型を用いた例がある[10-12]. 我々は最終的に高圧水素の粘性係数を測定することを目
的としており，より安全にそして少量の試料で測定でき るように，ワイヤ形状は小型化が可能な半円型を採用し た. Yusibani et al. [13]はこの方法を用いて室温で予備的な 試験を行っており, 本稿では, 新たに恒温槽を開発して, 装置定数である内部摩擦係数の温度依存性を決定した上 で，室温 $\left(23^{\circ} \mathrm{C}\right.$ または $\left.24^{\circ} \mathrm{C}\right)$ おび $50^{\circ} \mathrm{C}, 1 \mathrm{MPa}$ までの 窒素, ヘリウム，水素の粘性係数を測定したのでその結 果を報告する.

\section{2. 測定原理および測定装置}

\section{1 測定原理}

振動細線法では磁場中に設置した半円型の細線に電流 を流し，電磁力を発生させる，その電磁力により導線は 振動し, 導線両端に誘導起電力が発生するので, その誘 導起電力の変化を観察することで粘性係数を算出する. 細線の両端に直流パルス電圧を付加し，観察された誘導 起電力がどのように減衰していくかを観察することによ って粘性係数を求める方法と，付加する交流電圧の周波 数を変化させていくことで得られる誘導起電力から共鳴 曲線を描き，粘性係数を求める方法がある．本研究では 後者を採用し，実際の測定ではロックインアンプを用い て交流電圧の周波数を変化させ，誘導起電力を同様に口 ックインアンプで観察して，その共鳴曲線から粘性係数 を決定する. 図 2 に半円型センサの概略図を示す.
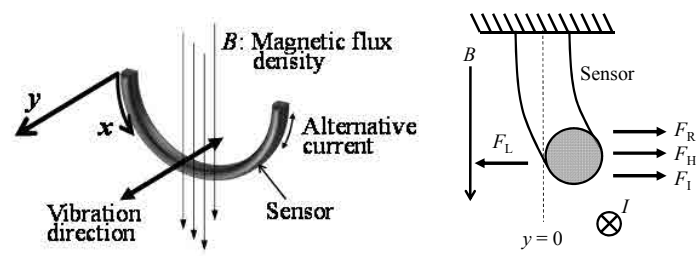

(a) Curved semi-circle wire

(b) Equilibrium of force Fig. 2 Schematic diagram of the curved semi-circle wire.

センサはタンクステン製で，直径 $50 \mu \mathrm{m}$ ，長さ $23.55 \mathrm{~mm}$ であり，重力の影響をなくすため，図 2 の向きにセンサ を設置した．図 2 の縦方向にサマリウムコバルト磁石で 磁場を発生させている，センサに電流を流寸前の位置を 基準点 $(y=0)$ とし, 実効值で数十 $\mu \mathrm{V}$ の交流電流を流すと, 図 2(b)のように, ワイヤの弾性力 $F_{\mathrm{R}}$, 流体から受ける力 $F_{\mathrm{H}}$, 内部摩擦による減衰力 $F_{\mathrm{I}}$, ローレンツ力 $F_{\mathrm{L}}$ が働き, 振動を開始する.

細線の磁場中における振動の運動方程式は式(1)となる. 


$$
\begin{gathered}
\pi r^{2} \rho_{\text {wire }} \frac{\partial^{2} y}{\partial t^{2}}=-\frac{\pi r^{4}}{4} E \frac{\partial^{4} y}{\partial x^{4}}-\left(D \frac{\partial y}{\partial t}+c^{\prime} \frac{\partial^{2} y}{\partial t^{2}}\right) \\
+B I_{0} \sin \left(\frac{\pi}{L} x\right) \sin (\omega t)-Q_{\text {vac }}^{-1} \omega \rho_{\text {wire }} \pi r^{2} \frac{\partial y}{\partial t}
\end{gathered}
$$

左辺は質量 $\times$ 加速度の項, 右辺第一項から $F_{\mathrm{R}}, F_{\mathrm{H}}, F_{\mathrm{L}}$, $F_{\mathrm{I}}$ である。この式(1)の境界条件は式(2)と(3)である.

$$
\begin{aligned}
& y(0, t)=y(L, t)=0 \\
& \left.\frac{\partial y}{\partial x}\right|_{x=0}=\left.\frac{\partial y}{\partial x}\right|_{x=L}=0
\end{aligned}
$$

この式のパラメータは式(4)-(8)で表される. $H_{n}^{(1)}(z)$ は八 ンケル関数である.

$$
\begin{aligned}
& D=\pi \rho_{\mathrm{gas}} r^{2} \omega k^{\prime}(m) \\
& c^{\prime}=\pi \rho_{\mathrm{gas}} r^{2} k(m) \\
& m=\frac{r}{2} \sqrt{\omega \rho_{\mathrm{gas}} / \eta} \\
& k+i k^{\prime}=1-\frac{\sqrt{2}(1-i)}{m} \frac{H_{1}^{(1)}(z)}{H_{0}^{(1)}(z)} \\
& z=\sqrt{2}(1+i) m
\end{aligned}
$$

このときに発生する誘導起電力は付加電流の周波数と同 位相と 90 度ずれた位相の成分に分けることができ, 式(9) のように書ける.

$$
V(t)=V_{i} \cos \omega t+V_{q} \sin \omega t
$$

式(9)の $V_{i}, V_{q}$ はそれぞれ式(10),(11)で表される.

$$
\begin{aligned}
& V_{i}=V_{\text {offset }}+\frac{4 \lambda^{2} \omega^{2}}{\left(\omega_{0}^{2}-\omega^{2}\right)^{2}+4 \lambda^{2} \omega^{2}} V_{\text {max }} \\
& V_{q}=\frac{2 \lambda \omega\left(\omega_{0}^{2}-\omega^{2}\right)}{\left(\omega_{0}^{2}-\omega^{2}\right)^{2}+4 \lambda^{2} \omega^{2}} V_{\text {max }}
\end{aligned}
$$

式(10)は共鳴曲線, 式(11)は分散曲線と呼ばれる. 図 3 に 一例として室温, $0.3 \mathrm{MPa}$ で水素を測定したときに得られ た共鳴曲線を示す. $V_{i}$ にはワイヤの抵抗によるオフセット が生じている，実際の測定ではロックインアンプで誘導 電圧を計測し, 得られる共鳴曲線にカーブフィッティン グを適用する. そして, 共鳴周波数 $\omega_{0}$ と $\omega_{1}, \omega_{2}$, 半值幅 $\lambda$ を求め, 式(12)にワイヤの密度 $\rho_{\text {wire, }}$ 半径 $r$, 内部摩擦係 数 $Q_{\mathrm{vac}}^{-1}$, 気体の密度 $\rho_{\mathrm{gas}}$ と共に代入し, 粘性係数を算出す る. ワイヤの密度 $\rho_{\text {wire }}$ は文献[14], 気体の密度 $\rho_{\text {gas }}$ は現在 最も信頼性の高い状態方程式と考えられる文献[15-17]を 各流体に適用し，これらをプログラミングしてカーブフ イッティングを実行した.

$$
2 \lambda=\omega_{2}-\omega_{1}=\frac{D+Q_{\text {vac }}^{-1} \omega_{0} \rho_{\text {wire }} \pi r^{2}}{\pi r^{2} \rho_{\text {wire }}+c^{\prime}}
$$

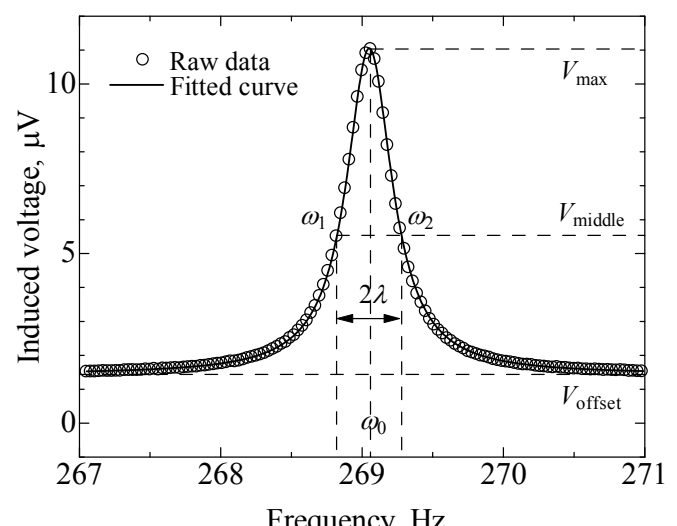

Fig. 3 Resonant curve obtained in measurement of hydrogen at room temperature $\left(23^{\circ} \mathrm{C}\right)$ and $0.3 \mathrm{MPa}$.

また，実際に気体の粘性係数を測定するには，センサの 特性を把握しておく必要がある，振動に関わるセンサの 特性は, 縦弾性係数や密度のほかに内部摩擦がある. 内 部摩擦は粘性と同じく振動における減衰に関わるので, 粘性効果と内部摩擦を明確に区別して把握しておく必要 がある．実際の測定では，真空引きをした状態で共鳴曲 線のピークの半值の周波数 $\omega_{1}, \omega_{2}$, 共鳴周波数 $\omega_{0}$ を式(13) に代入し，内部摩擦係数を算出する.

$$
Q_{\mathrm{vac}}^{-1}=\frac{\omega_{2}-\omega_{1}}{\omega_{0}}
$$

\section{2 測定装置}

本研究で開発した装置概略図および構成する各機器の 写真を図 4-10 に示寸. 装置は図 4 に示寸ように半円型セ ンサ, 恒温槽, パソコン, ロックインアンプ, 真空ポン プ，圧力センサ，真空圧センサ，白金温度計およびガス 供給ラインで構成されている. 図 5 はセンサ部モジュー ルの写真である. 中央部に半円型タングステンワイヤが 設置されている．外枠は絶縁するためにセラミックを用 いている．ワイヤはリード線と電気抵抗溶接で 2 つが直 角になるように溶接されている. モジュールサイズの関 係からワイヤ長さを $23.55 \mathrm{~mm}$ とし，この長さになるよう に位置を確定させた上で溶接を行っている．図 6 は 2000 倍に拡大したタングステンワイヤの SEM 写真である. ワ イヤを 10 点撮影し，画像から平均值としてワイヤの直径 $50.329 \mu \mathrm{m}$ を得た。 


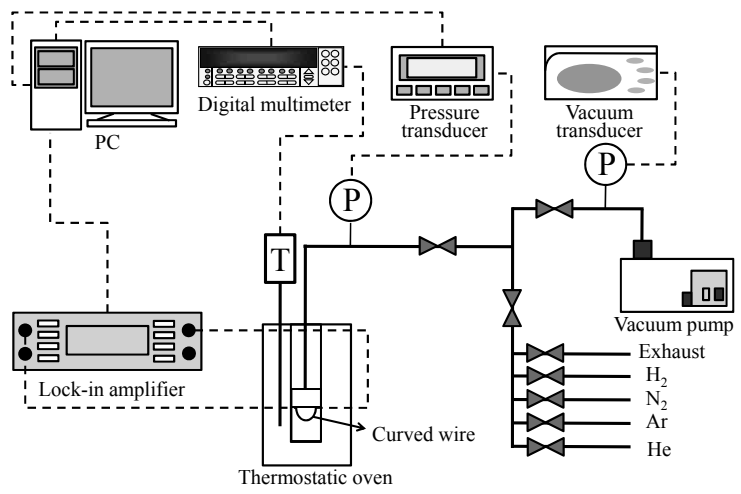

Fig. 4 Schematic diagram of the present apparatus.

図 7 は圧力容器であり, 他に遮熱板, 白金温度計, 信号 線が取り付けられている. 圧力容器は内径 $30 \mathrm{~mm}$, 容積 約 $42.4 \mathrm{~cm}^{3}$ であり, 少量の試料で測定が可能である. 図 8 はロックインアンプ(SIGNAL RECOVERY 社製 7265 型) である。このロックインアンプは内部発信器周波数をス イープしながら, 数十 $\mu \mathrm{V}$ という微小信号を検出すること が可能である.このロックインアンプを用いて駆動電圧, 周波数の刻み幅, 1 点を測定した後に次の周波数に移動す るまでの待機時間および積分時定数を決定することがで きる.

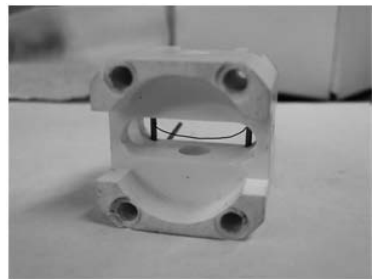

Fig. 5 Curved semi-circle wire module.

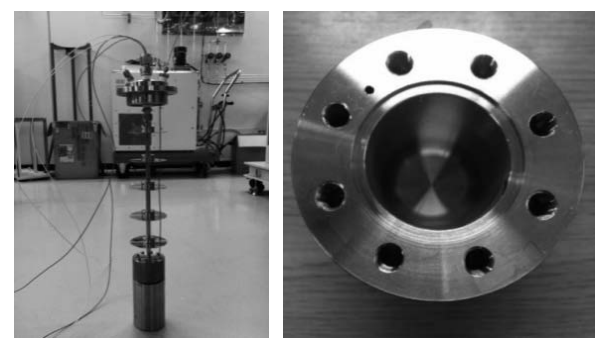

Fig. 7 Pressure vessel.

図 9 は内部摩擦係数を測定する際に真空引きをする真空 ポンプである. 最高真空到達度が $5.0 \times 10^{-4} \mathrm{~Pa}$ 程度のター ボ分子ポンプを使用し, $10^{-4} \mathrm{~Pa}$ オーダーまで真空引きをす る. 図 10 に示されている恒温槽は今回新たに開発された もので，500 ${ }^{\circ} \mathrm{C}$ までの昇温が可能である. このため図 7 に示した圧力容器に使用したパッキンは $500{ }^{\circ} \mathrm{C}$ に耐えら
れるようにインコネルにニッケルメッキを施したものを 採用した。

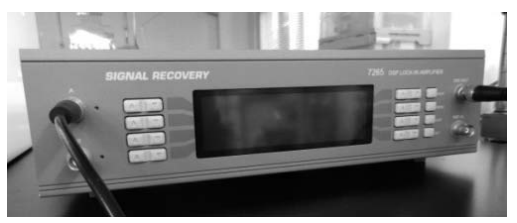

Fig. 8 Lock-in amplifier.

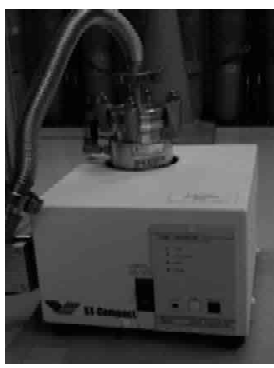

Fig. 9 Vacuum pump.

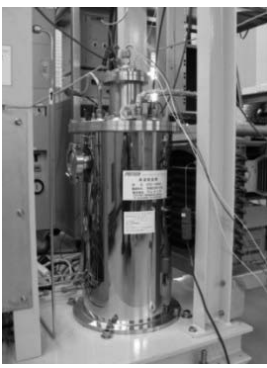

Fig. 10 Thermostatic oven.

\section{3．測定結果および検討}

\section{1 内部摩擦係数の測定結果}

内部摩擦係数は測定温度および圧力に依存するもので, 真空引きをした状態で共鳴曲線を出力し，ピークの半値 の周波数 $\omega_{1}, \omega_{2}$, 共鳴周波数 $\omega_{0}$ を式(13)に代入し, 算出 する. 図 11 に示すように真空ポンプを用いて $10^{-3} \mathrm{~Pa}$ から $10^{-4} \mathrm{~Pa}$ オーダーにまで真空引きをした状態で測定を行い, その圧力と内部摩擦係数をグラフにプロットして, 直線 近似した切片から $0 \mathrm{~Pa}$ での内部摩擦係数を決定した。こ の結果, 室温 $\left(24^{\circ} \mathrm{C}\right)$ および $50^{\circ} \mathrm{C}$ での内部摩擦係数はそれ ぞれ， $6.652 \times 10^{-4}, 5.222 \times 10^{-4}$ と決定された.

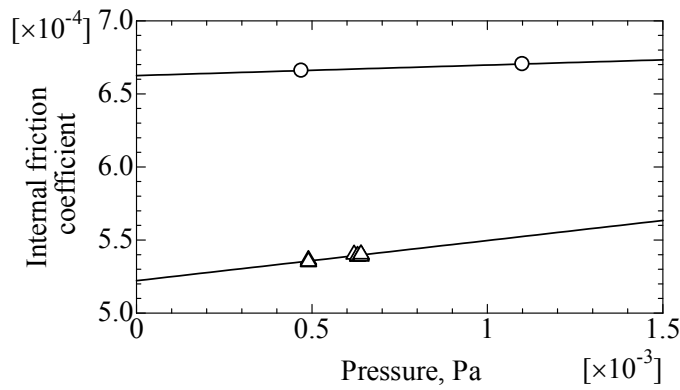

○ $24^{\circ} \mathrm{C} \quad \triangle 50{ }^{\circ} \mathrm{C}$

Fig. 11 Internal friction coefficient.

\section{2 粘性係数の測定結果}

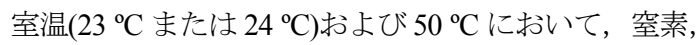
ヘリウム, 水素の粘性係数を測定した. 圧力は $0.3 \mathrm{MPa}$, 
$0.5 \mathrm{MPa}, 0.7 \mathrm{MPa}$ の 3 点で測定を行った。駆動電圧は 100 $\mu \mathrm{V}$ であり，周波数の刻み幅は $0.01 \mathrm{~Hz}$ ，共鳴角周波数の 前後 200 点において周波数を変化させた. 図 12-14に窒素, ヘリウム，水素の粘性係数測定結果と既存の粘性係数推 算式からの偏差を示す. また Yusibani et al. [13]の室温(23 $\left.{ }^{\circ} \mathrm{C}\right)$ のデータも比較として示している. 本測定では, 測定 中の温度変動幅は $10 \mathrm{mK}$ 以内で一定であった。 図 12(a)は 窒素の粘性係数測定結果であり, 図 12(b)は Lemmon and Jacobsen の推算式 [18]からの偏差を示している. 推算式 から計算される窒素の粘性係数は, 室温において大気圧 (0.1 MPa)から $1 \mathrm{MPa}$ まで圧力が変化すると, 相対的に 0.7 \%大きくなる. 一方, 温度依存性については $1 \mathrm{~K}$ 異な ったとしても粘性係数は $0.3 \%$ \%か変化しない. Lemmon and Jacobsen の推算式は不確かさ 2 \%であり, 本実測值 は全てその $\pm 2 \%$ 以内に入っている.
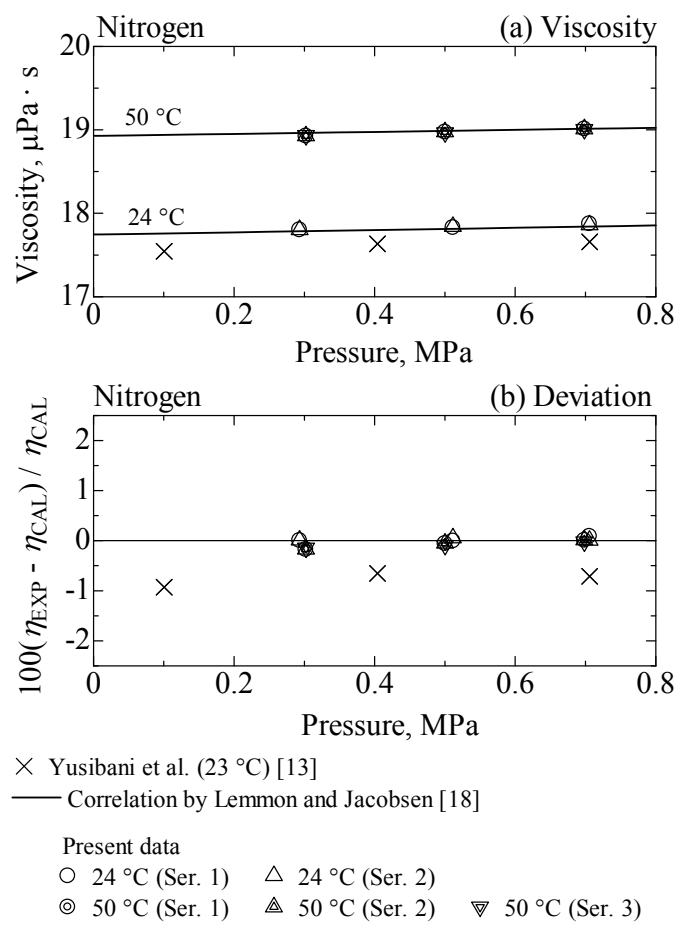

Fig. 12 Viscosity measurement results of nitrogen.

図 13(a)はへリウムの粘性係数測定結果である. ヘリウム の場合, 室温での圧力依存性は, 大気圧から $1 \mathrm{MPa}$ まで で $0.1 \%$ しか変化せず, また温度依存性についても $1 \mathrm{~K}$ で $0.2 \%$ しか変化しない. このため, 圧力・温度依存性はほ ぼないと言える. 図 13(b)はArp et al.の推算式[19]からの 偏差を示している。この式の不確かさは土10\%で本実測 值はその範囲内に含まれている. 図 14(a)は水素の粘性係 数測定結果である. 水素の温度依存性はへリウムと同程
度であり，圧力依存性については，大気圧から $1 \mathrm{MPa} ま$ でで，0.2\%大きくなる.図 14(b)は Yusibani et al.の推算式 [20]からの偏差である. Yusibani et al.の式の不確かさは土 $2 \%$ ありり，本測定結果は全てその $\pm 2 \%$ $\%$ 内に含まれて いる.
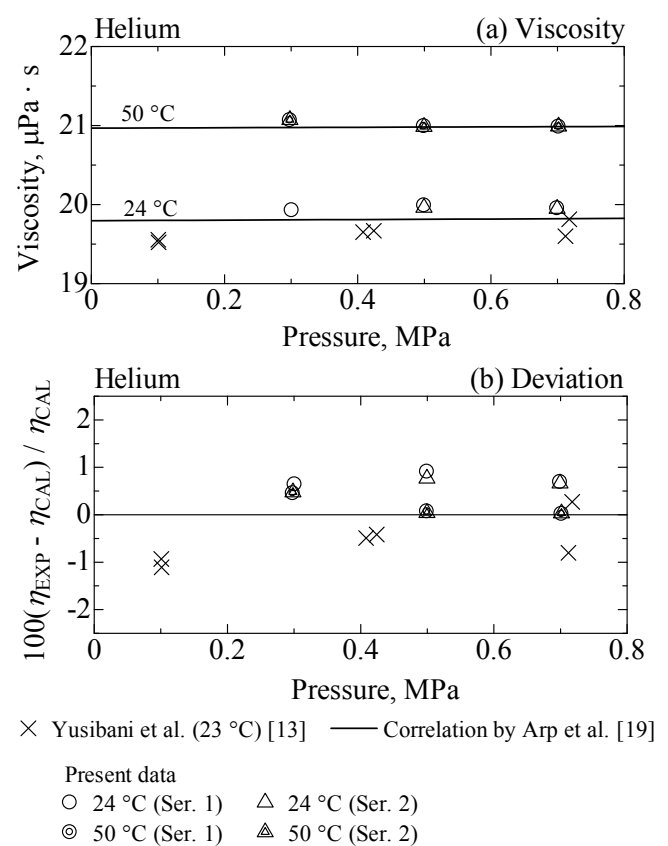

Fig. 13 Viscosity measurement results of helium.
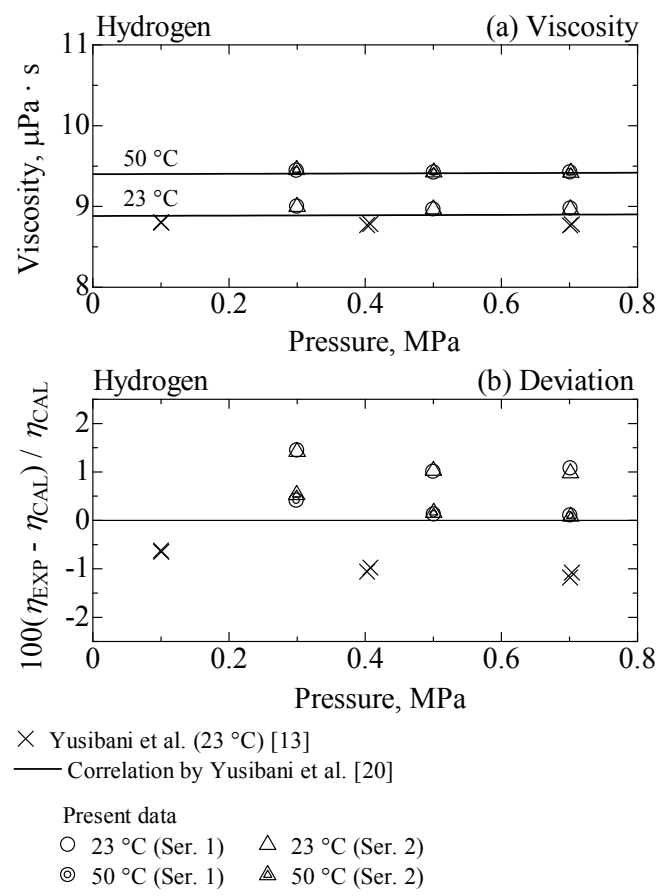

Fig. 14 Viscosity measurement results of hydrogen. 
ヘリウムおよび水素の室温のデータは， $50^{\circ} \mathrm{C}$ の結果と比 較し, 推算式からの相対偏差が系統的にやや大きくなっ ている.これは内部摩擦係数が影響している. 室温にお ける内部摩擦係数の值を仮に $1 \%$ 大きくした場合, 水素お よびヘリウムの粘性係数はそれぞれ相対的に $1 \%$ ， $0.5 \%$ 小さくなるのに対し, 窒素は $0.3 \%$ しか小さくならないこ とから, 水素, ヘリウムの室温のデータにおいても窒素 同様に推算式と良好に一致する傾向となる。したがって， 内部摩擦係数は粘性係数の算出において非常に重要なパ ラメータとなっている.

\section{4. 結 論}

水素の粘性係数を測定するため, 半円型振動細線式粘 性係数測定装置を開発した。 室温, $50{ }^{\circ} \mathrm{C}$ において，内部 摩擦係数 $Q_{\text {vac }}^{-1}$ 測定し, $0.3,0.5,0.7 \mathrm{MPa}$ の窒素, ヘリウム および水素の粘性係数を測定した. 測定值はそれぞれの 推算式からの偏差士2\%以内であった. 室温と $50{ }^{\circ} \mathrm{C}$ の結 果を比較すると, ヘリウム, 水素では室温の測定結果の 方が $50{ }^{\circ} \mathrm{C}$ の結果より推算式からの偏差が大きくなって いる. これは内部摩擦係数が関連している. 今後は, 本 測定值の正確な不確かさを算出し, 信頼性の高い実測值 ならびに推算式と比較することが必要である.また，高 温域の測定も行い, 最終的には高圧・高温域の測定デー タを細管法のデータと比較して, その信頼性を確認する 予定である。

\section{[謝辞]}

本研究は独立行政法人新エネルギー・産業技術総合開発 機構 (NEDO)による「水素先端科学基礎研究事業」の一 環として行った.ここに記し感謝の意を表す.

\section{NOMENCLATURE}

$B \quad$ : Magnetic flux density, T

E : Young's modulus of the wire, $\mathrm{Pa}$

$F_{\mathrm{H}} \quad$ : Fluid force, $\mathrm{N}$

$F_{\text {I }} \quad$ Force of restitution, $\mathrm{N}$

$F_{\mathrm{L}} \quad$ : Lorentz force, $\mathrm{N}$

$F_{\mathrm{R}} \quad$ : Elastic force of the wire, $\mathrm{N}$

$H_{n}^{(1)} \quad$ : First Hankel function

$I_{0} \quad$ : Driving current of electricity, $\mathrm{V}$

$L \quad$ : Length of the wire, $\mathrm{m}$

$Q_{\text {vac }}^{-1} \quad$ : Internal friction coefficient $r \quad:$ Radius of the wire, $\mathrm{m}$

$V_{i} \quad$ : Inphase component of resonant curve, $\mathrm{V}$

$V_{\max } \quad$ : Maximum induced voltage, $\mathrm{V}$

$V_{\text {offset }} \quad$ : Voltage offset of induced voltage, $\mathrm{V}$

$V_{q} \quad$ : Quadrature component of resonant curve, $\mathrm{V}$

$\eta \quad$ : Viscosity of sample gas, $\mathrm{Pa} \cdot \mathrm{s}$

$\lambda \quad$ : Half bandwidth, $\mathrm{Hz}$

$\rho_{\text {gas }} \quad$ : Density of the gas, $\mathrm{kg} / \mathrm{m}^{3}$

$\rho_{\text {wire }} \quad:$ Density of the wire, $\mathrm{kg} / \mathrm{m}^{3}$

$\omega \quad$ : Frequency, $\mathrm{Hz}$

$\omega_{0} \quad$ : Resonant frequency, $\mathrm{Hz}$

$\omega_{1} \quad$ : Small frequency of half line, $\mathrm{Hz}$

$\omega_{2} \quad$ : Large frequency of half line, $\mathrm{Hz}$

\section{参考文献}

[1] M. Hongo, H. Iwasaki; "Viscosity of Hydrogen and of Hydrogen-Ammonia Mixtures under Pressures", Rev. Phys. Chem. Japan, 48 (1978) 1-9.

[2] J. A. Gracki, G. P. Flynn, J. Ross; "Viscosity of Nitrogen, Helium, Hydrogen and Argon from -100 to $25^{\circ} \mathrm{C}$ up to 150-250 atm”, J. Chem. Phys., 51 (1969) 3856-3863.

[3] N. S. Rudenko, V. P. Slyusar; "Viscosity of Hydrogen at Constant Density over the Temperature Range 16.6-300 degrees K”, Ukr. Phys. J., 13 (1968) 656-659.

[4] N. V. Tsederberg, V. N. Popov, I. I. Andreev; "Experimental Investigation of the Viscosity of Hydrogen", Teploenergetika, 12 (1965) 84-85.

[5] A. K. Barua, M. Afzal, G. P. Flynn, J. Ross; "Viscosity of Hydrogen, Deuterium, Methane, and Carbon Monoxide from $-50^{\circ}$ to $150{ }^{\circ} \mathrm{C}$ below 200 Atmosphere", J. Chem. Phys., 41 (1964) 374-378.

[6] I. F. Golubev, V. A. Petrov (as given in I. F. Golubev 1970); "Viscosity of Gases and Gas Mixtures. A Handbook", (1953) Israel Program Sci. Transl.

[7] A. Michels, A. C. J. Schipper, W. H. Rintoul, "The Viscosity of Hydrogen and Deuterium at Pressures up to 2000 Atmospheres", Physica, 19 (1953) 1011-1028.

[8] E. Kuss; "High Pressure Research II: The Viscosity of Compressed Gases", Z. Angew. Phys., 4 (1952) 203-207.

[9] T. Uehara. K. Yoshimura, E. Yusibani, K. Shinzato, M. Kohno, Y. Takata; "Hydrogen Viscosity Measurements with Capillary Tube under High Pressure", Proceedings of the ASME 2013 11th International Conference on Nanochannels, Microchannels, and Minichannels, (2013) Paper No. ICNMM2013-73139.

[10] D. C. Carless, H. E. Hall, J. R. Hook; "Vibrating Wire Measurements in Liquid ${ }^{3}$ He. I. The Normal State", J. Low Temp. Phys., 50 (1983) 583-603.

[11] A. M. Guenault, V. Keith, C. J. Kennedy, S. G. Mussett, 
G. R. Pickett; "The Mechanical Behavior of a Vibrating Wire in Superfluid ${ }^{3} \mathrm{He}-\mathrm{B}$ in the Ballistic Limit", J. Low Temp. Phys., 62 (1986) 511-523.

[12] M. Morishita, T. Kuroda, A. Sawada, T. Satoh; "Mean Free Path Effects in Superfluid ${ }^{4} \mathrm{He}$ ", J. Low Temp. Phys., 76 (1989) 387-415.

[13] E. Yusibani, P. L. Woodfield, K. Shinzato, Y. Takata, “A Compact Curved Vibrating Wire Technique for Measurement of Hydrogen Gas Viscosity", Exp. Them. Fluid Sci., 47 (2013) 1-5.

[14] 日本熱物性学会; 「熱物性ハンドブック」，日本熱 物性学会編 (1990), 養賢堂.

[15] R. Span, E. W. Lemmon, R. T Jacobsen, W. Wagner, A. Yokozeki; "A Reference Equation of State for the Thermodynamic Properties of Nitrogen for Temperatures from 63.151 to $1000 \mathrm{~K}$ and Pressures to $2200 \mathrm{MPa}$, J. Phys. Chem. Ref. Data, 29 (2000) 1361-1433.

[16] R. D. McCarty, V. D. Arp; "A New Wide Range Equation of State for Helium", Adv. Cryo. Eng., 35 (1990) 1465-1475.

[17] N. Sakoda, K. Shindo, K. Motomura, K. Shinzato, M. Kohno, Y. Takata, M. Fujii; "Burnett PVT Measurements of Hydrogen and the Development of a Virial Equation of State at Pressures up to $100 \mathrm{MPa}$, Int. J. Thermophy., 33 (2012) 381-395.

[18] E. W. Lemmon, R. T Jacobsen; "Viscosity and Thermal Conductivity Equations for Nitrogen, Oxygen, Argon, and Air", Int. J. Thermophys., 25 (2004) 21-69.

[19] V. D. Arp, R. D. McCarty, D. G. Friend; "Thermophysical Properties of Helium-4 from 0.8 to $1500 \mathrm{~K}$ with Pressures to $2000 \mathrm{MPa}$, NIST Technical Note 1334 (revised) (1998).

[20] E. Yusibani, P. L. Woodfield, K. Shinzato, M. Kohno, Y. Takata, M. Fujii; "Prediction of Hydrogen Gas Viscosity at High Pressure and High Temperature", Jpn. J. Thermophys. Prop., 24 (2010) 21-27.

[Received Jan. 31, 2013, Accepted Oct. 22, 2013] 